\title{
Examining thermal conductivities of shallow subsurface materials for ground source heat pump utilization in the Pannonian part of Croatia
}

The Mining-Geology-Petroleum Engineering Bulletin UDC: 550.8

DOI: $10.17794 / \operatorname{rgn} .2018 .5 \cdot 3$

Original scientific paper

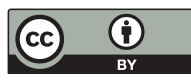

\author{
Staša Borović'; Kosta Urumović́'; Josip Terzić', Ivica Pavičić \\ ${ }^{1}$ Croatian Geological Survey, Sachsova 2, 10000 Zagreb, Croatia \\ ${ }^{2}$ University of Zagreb, Faculty of Mining, Geology and Petroleum Engineering, Pierottijeva 6, 10000 Zagreb, Croatia
}

\begin{abstract}
Thermogeological and hydrogeological properties of the shallow subsurface in the Croatian part of the Pannonian Basin System (PBS) were investigated in the context of its utilization for ground source heat pump (GSHP) system installations. Detailed borehole core determinations, sampling and thermal conductivity measurements were conducted for seven boreholes at four locations in diverse geological settings. The results of 418 measurements conducted on 82 sediment and rock samples were compiled and analysed in the context of existing collections of thermal conductivities from Germany and Switzerland which are frequently utilized for borehole heat exchanger (BHE) dimensioning in other countries. Discrepancies have been detected between thermal conductivity data from different geographical regions and geological settings. These results imply that local data sets should be further developed to enable accurate BHE sizing. In four boreholes, thermal response tests (TRTs) were also conducted, and the results were therefore compared with direct measurements on samples. The comparison demonstrated that in environments with significant groundwater flow (coarser-grained sediments) the laboratory measurements systematically underestimated the values of natural-scale thermal conductivity, while the discrepancies were low in finer-grained sedimentary environments. Consequently, TRTs are recommended for all installations in the presence of significant groundwater flow, while at locations with low flow velocity, the analogy to values cited in data collections can be used for small-scale installations. It is important to have a collection of measurements for local geological substances in cases when thermal response testing would not be economically feasible. The values reported in this paper can be a guideline for proper GSHP system dimensioning in order to achieve better performance, especially of small-scale systems in Croatia and other geologically comparable localities in the PBS area.
\end{abstract}

\section{Keywords:}

thermal conductivity, hydrogeological properties, ground source heat pumps, Pannonian Basin System, Croatia

\section{Introduction}

Utilization of ground source heat pumps for heating and cooling has the potential to become a key instrument for reducing the dependency on energy imports and lowering emissions by enhancing the decarbonisation of the heating and cooling market. Heating and refrigeration energy represents $50 \%$ of the total energy consumption in the EU, and Croatia is no exception. The demand for such energy is especially high in urbanized areas. According to the World Bank (World Bank Open Data, 2018) Croatia already faces a rather high degree of urbanisation $(56.7 \%)$, which is expected to increase in the coming decades. Therefore, strategies on the sustainable uptake of renewable energy supplies should be focused on urban areas.

Although around two thirds of the total installed capacities and more than $85 \%$ of all investments in the Eu-

Corresponding author: Staša Borović

sborovic@hgi-cgs.hr ropean geothermal sector are related to shallow geothermal energy utilization (EGEC Market Report, 2016), these simple and very adaptable heating and cooling techniques still suffer from a lack of visibility and awareness by the general public. Recent studies on the influence of public opinion of the renewable energy sources market penetration did not even include geothermal, shallow or deep, in its research (Nuortimo and Härkönen, 2018). Future technology penetration will definitely depend on the successful cases which will demonstrate the reliability and economic benefits of heat pump systems.

Since $70 \%$ of GSHP installations in Europe are situated in only four countries (Sweden, Germany, France and Switzerland) it is not surprising that, as the deployment of GSHP systems began in other countries, many of them have adopted reliable German and Swiss guidelines for the technology. Among drilling technology, heat exchanger and heat pump types, sizing and other guidelines, the aforementioned standards also include 
the collection of average thermal conductivities for different sediments and rocks which should be taken into calculations while planning the system design and borehole heat exchanger length. A sensitivity analysis on artificial heat injection has found that the design process is the most sensitive to thermal conductivity of solids, porosity, heat capacity of solids and the longitudinal dispersivity, in that order. In their review of GSHP system efficiency, they also report that the most important factor in dimensioning BHE-coupled GSHP systems is the ground thermal conductivity, especially for larger installations, accentuating that not only the average thermal conductivity, but also its vertical distribution is relevant.

By adopting thermal parameters from foreign standards, formulated for different geological, thermogeological and hydrogeological conditions in the subsurface, systems in different environments can be sized improperly, leading to low coefficients of performance and serving as bad publicity for the technology in general. Therefore, this paper presents and discusses the thermal conductivity values measured on borehole samples from locations in the towns and cities in the Croatian part of the PBS, which can be useful for future applications in the investigated region, but also as a starting point for planning future studies using a denser sampling network in typical environments.

\section{Research area}

The Pannonian part of Croatia is situated on the southwestern rim of the PBS (see Figure 1). It is characterized by clastic sedimentary sequences of Paratethys Sea and Lake Pannon which are a few kilometres thick (Mandić et al., 2015; Velić et al., 2012) and modern and sub-modern fluvial sedimentation (Hećimović, 2009). That is why the presence of unconsolidated clastic sediments and clastic sedimentary rocks were anticipated at depths usually considered for the BHE placement. These materials have very variable granulometric properties, porosity and permeability, which influence their ability of groundwater retention and flow (Urumović and Urumović Sr, 2016). Groundwater is frequently present very close to the surface, in the aquifers with intergranular porosity. Saturation of pore space by different fluids (air or water) influences thermal properties of the materials, and groundwater flow in the aquifers contributes to heat transfer by convection (Banks, 2008).

Thermal parameters of the subsurface relevant for GSHP utilization vary in accordance with diverse genesis and lithology of the two prominent geological regions: The Pannonian part in the NE and the Dinaric part in the SW of Croatia. Drilling sites in the Pannonian part (see Figure 1) were chosen on the basis of sediments' grain size prediction and the known presence or absence of aquifers with significant flow velocities.

\section{Methodology}

Core drilling was performed at all locations, followed by detailed core determination and sampling. The collected soil and rock samples were analysed for their lithological and thermal properties (see Figure 2).

In the lowland parts of the investigated area, sediments with intergranular porosity dominate at depths usually considered for borehole heat exchanger installations. In the boreholes in Čakovec, Osijek, Požega and Zagreb - alluvium (Zagreb-AL) double polyethylene Upipe $(32 \times 2.9 \mathrm{~mm})$ borehole heat exchangers were in-

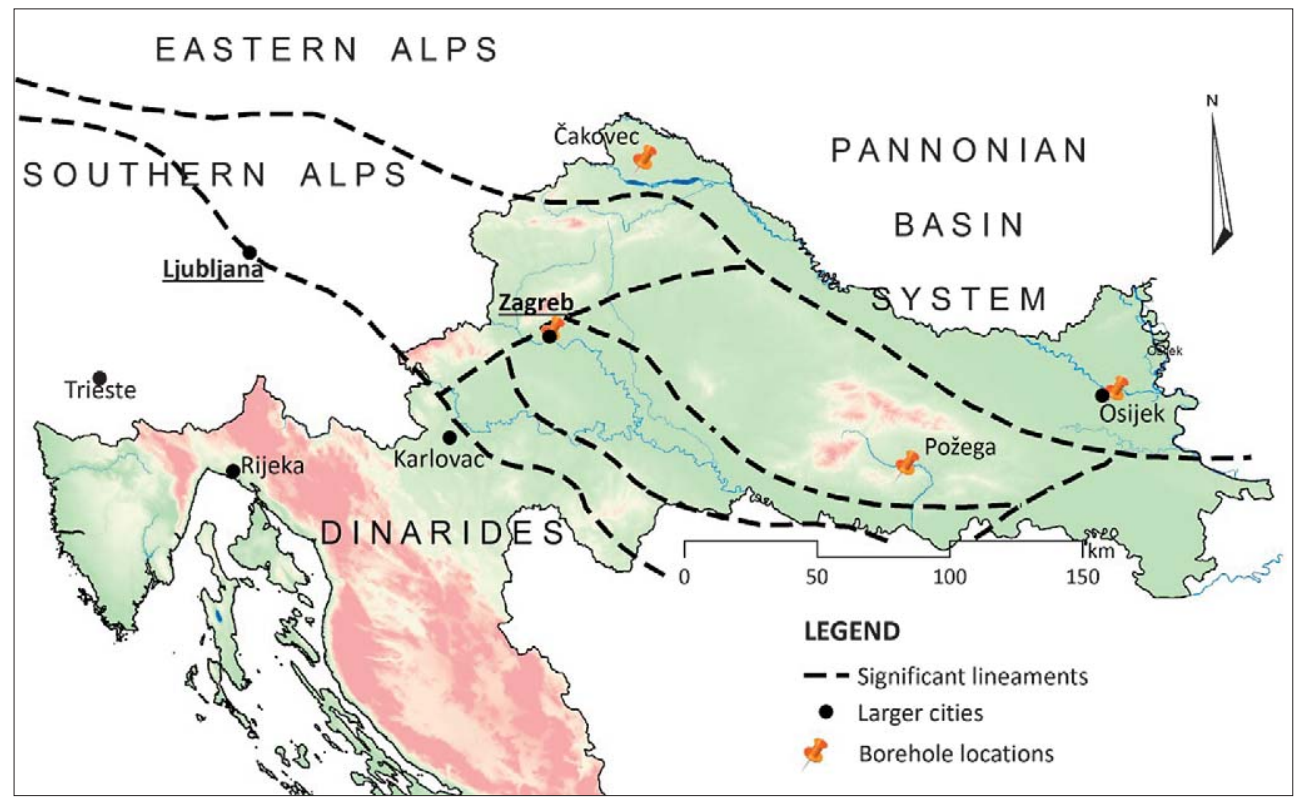

Figure 1: The position of Croatia in relation to major European tectonic units (adopted from Borović et al. (2016)); tectonic units delineated according to Lučić et al. (2001), Tari and Pamić (1998) and Velić et al. (2012) 


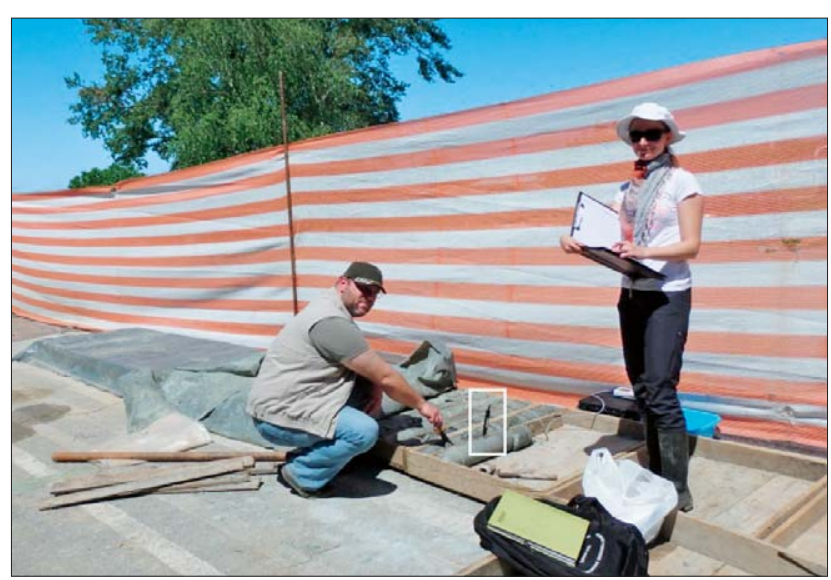

Figure 2: Detailed borehole core determination and in situ measurement of thermal properties in Čakovec. Needle probe inserted into the core is emphasized by a white rectangle.

stalled into three $100 \mathrm{~m}$ deep exploratory boreholes and one $130 \mathrm{~m}$ deep borehole, Zagreb-AL. The outer diameter of the boreholes is $152 \mathrm{~mm}$ and after installation of borehole heat exchanger, the boreholes were grouted by a thermally enhanced grout. Thermal response tests were performed at all four locations.

Other boreholes in the Podsljeme urbanized zone of the City of Zagreb (Zagreb-PUZ) were drilled in its montane hinterland. These boreholes (Lukšić - $150 \mathrm{~m}$ and Teškovec - $200 \mathrm{~m}$ ) were drilled for a different purpose: research on landslide hazards. They were also core drilled and engineering geological determination was performed (Miklin et al., 2016; Sokolić et al., 2016). Since the thermal conductivity of sediments and rocks influences their geomechanical properties, it was also measured in the scope of the research. At these locations, no thermal response tests were performed.

Direct measurement of rock and sediment thermal properties was conducted by ISOMET 2114 - Thermal Properties Analyzer instrument. The device is designed for both indoor and outdoor measurements in geological investigations (Applied Precision, 2013). The manufacturer provided a calibration certificate for the unit, which is presented in Table 1.

The principle of operation of the apparatus is a modified hot wire method described by Carslaw and Jaeger (1959) and Prelovšek and Uran (1984). The measurement is based on the analysis of the temperature response generated by each material to heat impulses induced by electrical heating. The instrument applies transient heat transfer by a probe, which is placed in direct contact with the material being investigated. A transient heating signal is transmitted to the sample and its decay is monitored by the probe. Thermal conductivity and volume heat capacity are obtained from the decay curve, while thermal diffusivity is calculated as a quotient of the two values (Kušnerová et al., 2013). The instrument is equipped with a needle probe for unconsolidated sedi-
Table 1: Characteristics of ISOMET 2114 measurement apparatus

\begin{tabular}{|l|l|l|}
\hline $\begin{array}{l}\text { Measured } \\
\text { parameter }\end{array}$ & Value span & Accuracy \\
\hline \multirow{2}{*}{$\begin{array}{l}\text { Thermal } \\
\text { conductivity }\end{array}$} & $\begin{array}{l}0.015-0.70 \\
\mathrm{Wm}^{-1} \mathrm{~K}^{-1}\end{array}$ & $\begin{array}{l}5 \% \text { reading } \\
+0.001 \mathrm{Wm}^{-1} \mathrm{~K}^{-1}\end{array}$ \\
\cline { 2 - 3 } & $0.70-6.0 \mathrm{Wm}^{-1} \mathrm{~K}^{-1}$ & $10 \%$ reading \\
\hline $\begin{array}{l}\text { Volumetric heat } \\
\text { capacity }\end{array}$ & $\begin{array}{l}4^{*} 10^{4}-3 * 10^{6} \\
\mathrm{Jm}^{-3} \mathrm{~K}^{-1}\end{array}$ & $\begin{array}{l}15 \% \text { reading } \\
+1 * 10^{3} \mathrm{Jm}^{-3} \mathrm{~K}^{-1}\end{array}$ \\
\hline Temperature & $-20-(+70)^{\circ} \mathrm{C}$ & $\pm 1{ }^{\circ} \mathrm{C}$ \\
\hline
\end{tabular}

Source: Applied Precision (2013)

ments and a surface probe for hard rock samples which must be prepared before the measurement. For measurements using a needle probe, no sample preparation is necessary. The needle with sensors could be fully inserted into the core because it is shorter than the borehole diameter. After the core was taken out of the boreholes it was stored in caskets and covered to preserve the humidity content as close as possible to the original one. However, since the drilling was carried out using light bentonite drilling fluid, it is obvious that the water contained in the core did not correspond exactly to the original content at depth, nor could such conditions be preserved. A surface probe was used for measurements on rock samples, namely, greenschist, marble and sandstone.

Intervals of the cores for thermal properties' measurements were chosen based on borehole core lithology determination and the properties of characteristic rocks and sediments were measured. In the boreholes where highly similar lithological members were repeatedly present, the measurements were conducted on a few samples of the same lithology, and the arithmetic mean was taken as a representative for the rest of such materials in the calculations of weighted average thermal conductivity along the borehole length.

This paper analyses the thermal conductivities of sediments and rocks measured directly on the samples. For the boreholes with installed BHEs, the results obtained by direct measurements were compared to the results obtained by distributed thermal response testing (DTRT). More details on the performed thermal response testing and data analyses have been published in previous papers (Soldo et al., 2016a; Soldo et al., 2016b).

\section{Results and discussion}

Simplified lithological cross-sections based on the determination of borehole core materials are presented in Figure 3 and Figure 4. Rock and sediment thermal conductivities were measured on a total of 82 samples and a total of 418 measurements were performed. The number of samples and measurements per location is specified in Table 2.

It is visible in Table 2 that only unconsolidated sediments were encountered at all but one investigated local- 
ČK-1

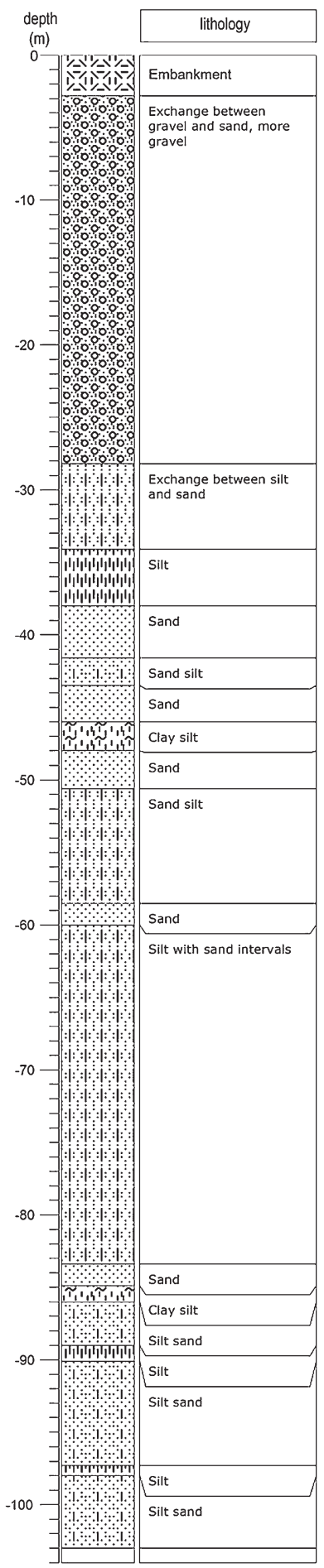

OS-1

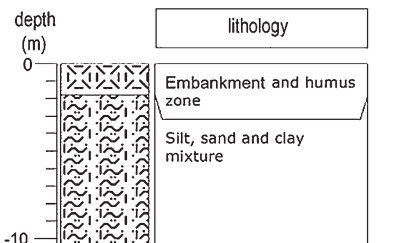

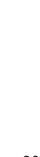

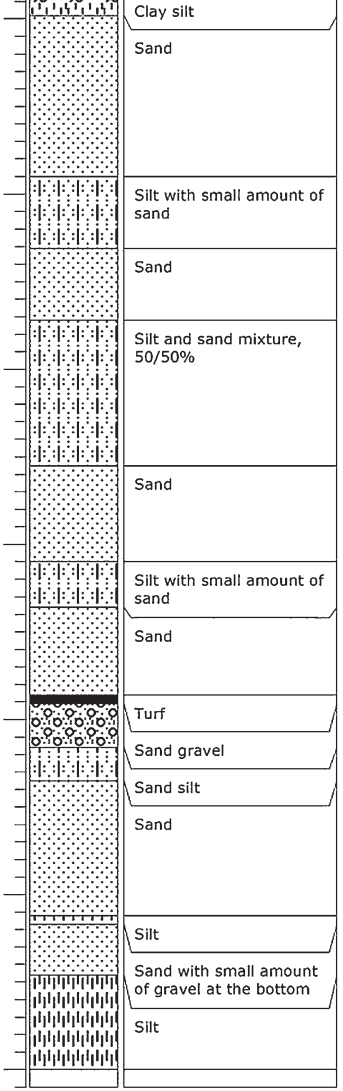

PŽ-1

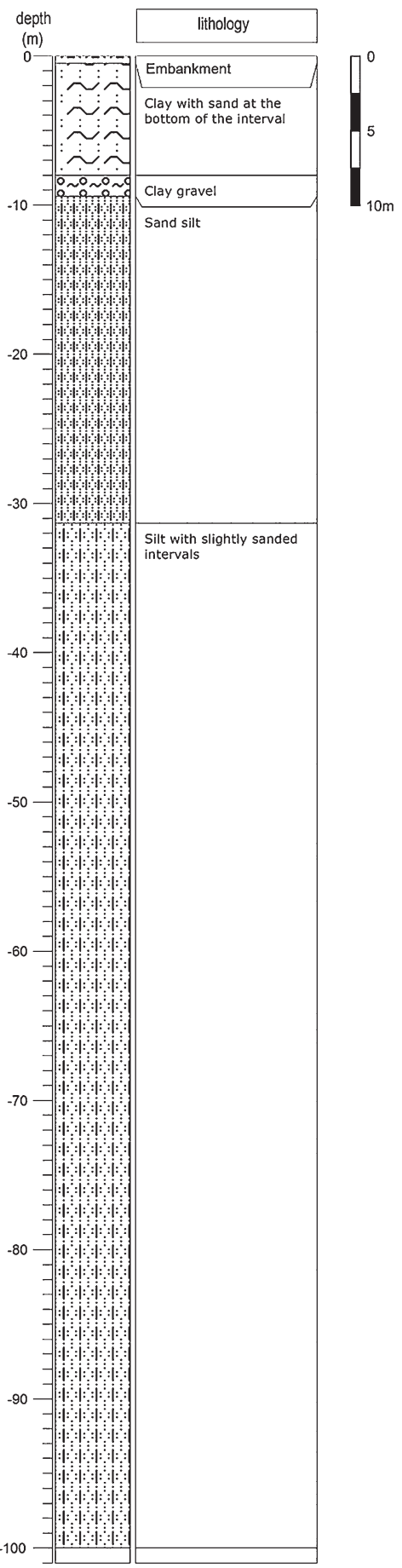

Figure 3: Simplified lithological cross-sections of the boreholes in Čakovec, Osijek and Požega (from left to right)

ity in the Pannonian part of Croatia. Zagreb-PUZ clearly differs from other localities because it is not situated in an alluvial plain but at the foothills of a mountain, so thinner sedimentary cover was anticipated. It can also be noted that the number of samples analysed in Požega is lower than at the other localities. The reason for that is a very uniform lithology, shown in the right-hand side of Figure 3.

A few interesting regularities can be observed in Table 3. It is visible that at all four Croatian localities situated in areas with thick sedimentary cover, the thermal conductivities decrease with a decrease in grain size. 

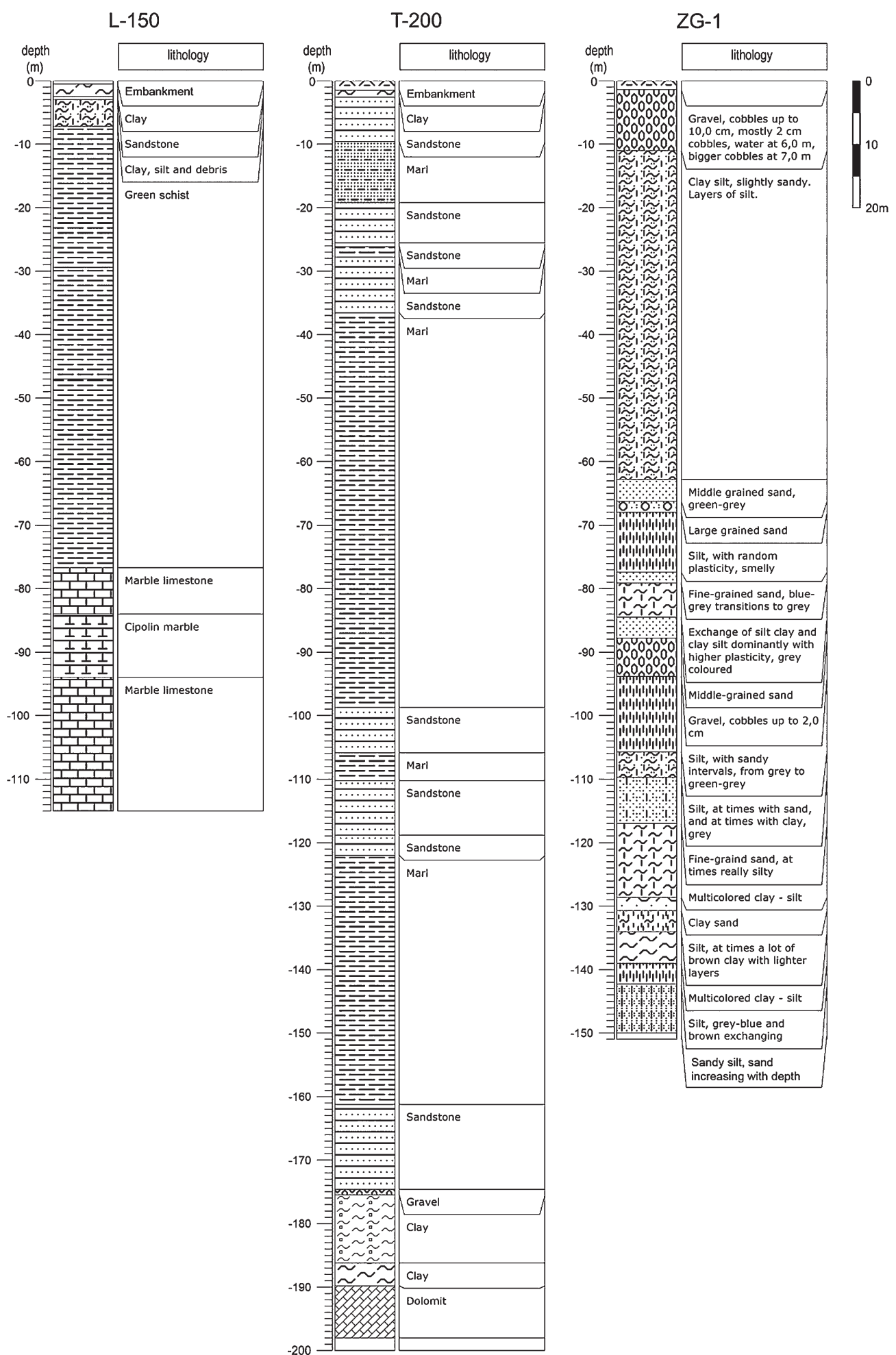

Figure 4: Simplified lithological cross-sections of the boreholes in Zagreb-PUZ (left and central) and Zagreb-AL (right)

Comparing these findings with the values quoted in German VDI 4640 and Swiss SIA 384/6 (Eugster et al., 2010) guidelines for ground source heat pump installation, it can be noted that in those countries the standards report very high thermal conductivities for sands in comparison to the Croatian samples.
Gravelly sediments from all the localities in Croatia display higher thermal conductivities than those reported in German and Swiss standards, while the opposite is valid for finer-grained sediments, especially clay.

Considering the rock samples, greenschist data could not be compared to the consulted standards, since nei- 
ther VDI nor SIA include greenschist values. This fact underlines one of the problems which can arise when using foreign standards. For both marls and sandstones, major discrepancies are present. It can be assumed that the sandstones on which the measurements were conducted were much older than the ones found in the $\mathrm{Za}-$ greb area. Namely, the most common sandstones found at the surface and usual depths for BHE installation in Germany are Buntsandsteins of Lower Triassic age (Butler et al., 2011; Kunkel, 2016; Sass and Burbaum, 2010), while in the Zagreb-PUZ area, they are of Pontian age. Older sandstones have experienced a higher degree of compaction and consolidation so they display higher thermal conductivities, owing to the fact that thermal conductivities of rock forming minerals are tenfold or even higher than those of fluids found in the pore spaces. Measurements on quartz sandstones of similar age (Permian-Triassic) were reported in Croatia in Borović (2015), with values of thermal conductivity reaching up

Table 2: Number of samples and measurements from the locations in the Pannonian part of Croatia

\begin{tabular}{|l|l|l|l|l|}
\hline \multirow{2}{*}{ Locations } & \multicolumn{2}{l|}{$\mathrm{N}^{\circ}$ of samples } & \multicolumn{2}{l|}{$\mathrm{N}^{\circ}$ of measurements } \\
\cline { 2 - 5 } & Rock & Sediment & Rock & Sediment \\
\hline Čakovec & 0 & 18 & 0 & 90 \\
\hline Osijek & 0 & 18 & 0 & 86 \\
\hline Požega & 0 & 7 & 0 & 42 \\
\hline Zagreb-AL & 0 & 16 & 0 & 85 \\
\hline Zagreb-PUZ & 15 & 8 & 75 & 40 \\
\hline TOTAL & 15 & 67 & 75 & 343 \\
\hline
\end{tabular}

to $6.24 \mathrm{Wm}^{-1} \mathrm{~K}^{-1}$, but those samples were taken from outcrops in a remote and unpopulated mountainous area where no heat pump systems will be installed in the near future, so the data is not considered relevant for the present discussion. An extreme discrepancy in values for marl is assumed to be caused by the different proportions of siliciclastic and carbonate components in different geological settings. The proportion of carbonate components in marls from Zagreb-PUZ area is reported in Miklin et al. (2016). However, since the composition of marls in consulted guidelines is not displayed, there is no basis for comparison.

In Table 4, a comparison of thermal conductivities obtained along the borehole length by calculation from laboratory measurements on samples and by DTRT measurements is presented. It can be observed that laboratory measurements on samples systematically underestimate thermal conductivity of the subsurface in comparison to DTRT data which measure heat transfer in real scale. This is caused by the fact that the TRT device measures total heat transfer via registering temperature difference. In the presence of aquifers, the heat is transferred by both conduction and convection due to groundwater flow. In the subsequent calculations, all heat transfer is attributed to conduction, according to predominantly used models (Yang et al., 2010). Such a calculation obviously leads to an unrealistic increase in thermal conductivity of the subsurface.

Even amongst well known standards which offer the collections of thermal conductivity by rock/sediment type, like the above mentioned German VDI and the

Table 3: Measured thermal conductivities of sediments and rocks in the Pannonian part of Croatia, $\lambda\left[\mathrm{Wm}^{-1} \mathrm{~K}^{-1}\right]$

\begin{tabular}{|c|c|c|c|c|c|c|c|c|}
\hline & Čakovec & Osijek & Požega & Zagreb - AL & Zagreb - PUZ & \begin{tabular}{|l|} 
AVERAGE \\
(HR)
\end{tabular} & $\begin{array}{l}\text { VDI } 4640 \\
\text { (D) }\end{array}$ & \begin{tabular}{|l} 
SIA 384/6 \\
(SWI)
\end{tabular} \\
\hline \multicolumn{9}{|c|}{ SEDIMENTS } \\
\hline gravel & 2.21 & 2.30 & & 2.50 & & 2.34 & 1.8 & 1.7 \\
\hline sand & 1.81 & 1.62 & 1.50 & 1.40 & 1.46 & 1.56 & 2.4 & 2.3 \\
\hline silt & 1.50 & 1.61 & 1.52 & 1.35 & 1.90 & 1.58 & \multirow{2}{*}{1.8} & \\
\hline clay & 1.40 & & 1.28 & 1.10 & 1.22 & 1.25 & & 1.4 \\
\hline \multicolumn{9}{|l|}{ ROCKS } \\
\hline greenschist & \multirow{3}{*}{\multicolumn{4}{|c|}{ No rocks were encounteredat investigated depths. }} & 1.91 & & & \\
\hline marl & & & & & 0.98 & & 2.3 & 2.1 \\
\hline sandstone & & & & & 1.55 & & 2.8 & 2.3 \\
\hline
\end{tabular}

Table 4: Results of thermal conductivity, $\lambda\left[\mathrm{Wm}^{-1} \mathrm{~K}^{-1}\right]$, calculated along the entire borehole length

\begin{tabular}{|l|l|l|l|}
\hline \multirow{2}{*}{} & \multicolumn{2}{|l|}{ Measurement technique } & Discrepancy (\%) \\
\cline { 2 - 4 } & LAB & DTRT* & LAB-DTRT \\
\hline Čakovec & 1.71 & 2.10 & -18.57 \\
\hline Osijek & 1.81 & 1.98 & -8.59 \\
\hline Požega & 1.30 & 1.65 & -21.21 \\
\hline Zagreb & 1.51 & 1.69 & -10.65 \\
\hline
\end{tabular}

*DTRT data adopted from Soldo et al. (2016b)
Swiss SIA, thermal conductivity is reported for the subsurface material and occasionally its water content, but not groundwater flow (Dehkrodi and Schincariol, 2013). Gehlin (2002) concluded that groundwater flow in a porous medium significantly changes the temperature in and around a borehole. These results show approximately 5 and $2^{\circ} \mathrm{C}$ change in loop temperatures under groundwater velocities of $10^{-6}$ and $10^{-7} \mathrm{~m} / \mathrm{s}$, respectively. These changes would approximately equal a tenfold and twofold increase in effective thermal con- 
ductivity, respectively. Dehkordi and Schincariol (2013) posit that Darcy velocities of $10^{-7} \mathrm{~m} / \mathrm{s}$ and higher cannot be disregarded as they also have a substantial impact on the shape and size of the thermal plume which has formed around BHE. Groundwater flow enhances thermal recovery to initial conditions even more effectively and the impact is noticeable if fluxes are higher than $10^{-8} \mathrm{~m} / \mathrm{s}$. Groundwater flow proved to be the most important factor in thermal recovery of the subsurface. Higher thermal conductivity of the ground solids greatly heightens the thermal efficiency of a BHE by improving the heat transport; conversely, it causes larger thermal plumes. Since the thermal gradient drops severely and quickly when the GSHP is shut down, thermal conductivity has a relatively minor impact on thermal recovery, while the hydraulic gradient remains unchanged and enhances plume dissipation by convection. Such flow velocities are expected in the majority of the locations in Croatia in gravels, sands and even some silts (Bačani, 2006), which has a positive impact on the overall GSHP performance indicators.

\section{Conclusions}

It is well known that the proper dimensioning of the GSHP system, without either over- or under-sizing it, is the main prerequisite to achieve favourable performance factors of the system (Banks, 2008; Busby et al., 2009). Since the possibility to extract the necessary amount of heat from the ground or reject it into the ground depends on the thermal properties of the subsurface, this paper offers some insight into thermal conductivities in the Croatian part of the PBS at depths usually considered for borehole heat exchanger installation in the scope of GSHP systems.

Although thermal response testing is by far the most reliable method of determining subsurface thermal conductivity in natural scale conditions, its performance for smaller installations is often not economically justifiable and analogy to existing measurements is applied. This paper offers the values of thermal conductivities measured on laboratory size samples from different locations in Croatia (see Table 3). A clear regularity of increasing thermal conductivity with an increase of grain size was observed in sediments. For some rocks (e.g. marls and sandstones), a discrepancy with VDI (VDI, 2001) and SIA (SIA, 2010) standards was noted. Also, some rocks present in Croatia are simply not part of foreign standards, as exemplified in this paper by greenschist in Zagreb-PUZ area.

The presented research also demonstrates that measurements on laboratory size samples systematically underestimate the thermal conductivities in comparison to TRTs. It is clear that measurements on laboratory size samples cannot take into account the major quantities of heat that are being transferred by groundwater movement. Measurement in natural-scale conditions (espe- cially DTRT) is obviously a more accurate representation of the real conditions present when a heat pump system is being constructed. Such regularity is expected and logical. In case measurements on samples are available and a presence of aquifers was identified during the drilling, according to presented results in Croatian part of the PBS, one can give a fair engineering judgment that the thermal conductivity along the borehole length will be at least $10 \%$ higher than indicated by such measurements. This fact has implications on the BHE dimensioning. However, one should always be aware of all the limitations and advantages of needle- and plane sourcethermal probes used for measurements in the scope of this research, as discussed in detail by Vieira et al. (2017).

As suggested by Rybach and Eugster (2010), rapid growth of GSHP installations is currently taking place in many countries and development is also foreseen in countries where GHP systems have been rarely deployed so far. Quality design and performance of the systems should encourage faster GSHP technology penetration. As it was exemplified by the comparison of Croatian data to the German and Swiss standards, having the measurements for materials collected in geographically close and geologically similar areas has a significant value in cases when thermal response testing is not an economically viable option. In that regard, the values reported in this paper can serve as a guideline for the proper system dimensioning and, consequentially, toward achieving higher performance factors, especially for small-scale GSHP systems in Croatia and other geologically comparable localities in the PBS area.

\section{Acknowledgments}

The data presented for Čakovec, Osijek, Požega and Zagreb-AL boreholes was acquired in the scope of the EU IPA funded project "Research and the Promotion of the Use of Shallow Geothermal Potential in Croatia", acronym GeoMapping (grant no. IPA2007/HR/16IPO/ 001-040506). Data for other locations in the City of Zagreb was collected during the implementation of a project "Detailed engineering geological map of the Podsljeme urbanized zone" funded by the City of Zagreb (contract no. 327/2016). The authors would like to thank Željko Miklin, Jasmina Martinčević Lazar, Tomislav Novosel and Laszlo Podolszki for borehole core determinations in the Podsljeme urbanized zone. The original manuscript was significantly improved owing to constructive comments made by two anonymous reviewers, so the authors wish to sincerely thank them.

\section{References}

Applied Precision (2013): ISOMET 2114 Thermal properties analyzer. User's Guide Version 011213, Bratislava, 32 p.

Bačani, A. (2006): Hidrogeologija I (Hydrogeology I). University of Zagreb - Faculty of mining, geology and petroleum engineering, Zagreb, 198 p. 
Banks, D. (2008): An Introduction to Thermogeology $2^{\text {nd }}$ edition. Wiley-Blackwell, Oxford, UK, 526 p.

Borović, S. (2015): Integrated hydrogeological-hydrogeochemical model of Daruvar geothermal aquifer. $\mathrm{PhD}$ thesis, University of Zagreb - Faculty of mining, geology and petroleum engineering, $148 \mathrm{p}$.

Borović, S., Marković, T., Larva, O., Brkić, Ž. and Mraz, V. (2016): Mineral and thermal waters in the Croatian part of the Pannonian basin. In: Papić, P. (ed.): Mineral and Thermal Waters of Southeastern Europe. - Springer, Cham, $31-45,171$.

Busby, J., Lewis, M., Reeves, H. and Lawley, R. (2009): Initial geological considerations before installing ground source heat pump systems. Quarterly Journal of Engineering Geology and Hydrogeology, 42, 3, 295-306.

Butler, R. J., Brusatte, S. L., Reich, M., Nesbitt, S. J., Schoch, R. R. and Hornung, J. J. (2011): The sail-backed reptile Ctenosauriscus from the latest Early Triassic of Germany and the timing and biogeography of the early archosaur radiation. PLoS One, 6, 10, e25693.

Carslaw, H. S. and Jaeger, J. C. (1959): Conduction of Heat in Solids $2^{\text {nd }}$ edition, Oxford Science Publications, Oxford UK, $510 \mathrm{p}$.

Dehkordi, S. E. and Schincariol, R. A. (2013): Effect of thermal-hydrogeological and borehole heat exchanger properties on performance and impact of vertical closed-loop geothermal heat pump systems. Hydrogeology Journal, $22,1,189-203$.

EC (2016): An EU Strategy on Heating and Cooling. European Commission, Brussels, 13 p.

EGEC (2016): EGEC Market Report 2016, European Geothermal Energy Council, URL: https://www.egec.org/wpcontent/uploads/2017/05/EGEC-Geothermal-Market-Report_KF_final_web.pdf (Accessed $3^{\text {rd }}$ November 2018)

Eugster, W., Pahud, D., Rohner, E. and Signorelli, S. (2010): Sondes géothermiques. SIA 384/6:2010 Bâtiment, génie civil. Norme suisse SN 546 384/6. Société suisse des ingénieurs et des architectes, Zurich, $76 \mathrm{p}$.

Gehlin, S. (2002): Thermal Response Test - Method Development and Evaluation. $\mathrm{PhD}$ thesis, Luleå University of Technology, $191 \mathrm{p}$.

Hećimović, I. (2009): Kvartar (Quaternary): In: Velić, I. and Vlahović, I. (eds.): Tumač Osnovne geološke karte Republike Hrvatske 1:300.000 (Explanatory notes for the Basic Geological Map of the Republic of Croatia 1:300,000), Hrvatski geološki institut, Zagreb, 95-101, 142 p.

Kunkel, C. C. (2016): Facies and Aquifer Characterization of the German Triassic Buntsandstein in Central Germany. $\mathrm{PhD}$ thesis, Friedrich Schiller University of Jena, 223 p.

Kušnerová, M., Valíček, J., Harničárová, M., Hryniewicz, T., Rokosz, K., Palková, Z., Václavík, V., Řepka, M. and Bendová, M. (2013): A Proposal for Simplifying the Method of Evaluation of Uncertainties in Measurement Results. Measurements Science Review, 13, 1, 1-6.

Lučić, D., Saftić, B., Krizmanić, K., Prelogović, E., Britvić, V., Mesić, I. and Tadej, J. (2001): The Neogene evolution and hydrocarbon potential of the Pannonian Basin in Croatia. Marine and Petroleum Geology, 18, 133-147.
Mandić, O., Kurečić, T., Neubauer, T. A. and Harzhauser, M. (2015): Stratigraphic and paleogeographic significance of lacustrine mollusks from the Pliocene Viviparus beds in central Croatia. Geologia Croatica, 68, 3, 179-207.

Miklin, Ž., Podolszki, L., Novosel, T., Borović, S., Lazar, J. M., Burić, H., Bakrač, K., Miknić, M., Belak, M., Stanić, N., Sokolić, Ž., Ofak, J., Sokolić I. and Dobrilović, I. (2016): Strateške strukturne bušotine T-200 i L-150 za potrebe izrade inženjerskogeološke karte podsljemenske urbanizirane zone (Strategic structural boreholes T-200 and L-150 for the purpose of producing an engineering geological map of the Podsljeme urbanized zone), Geotehnički studio Ltd. and Hrvatski geološki institut, Zagreb, $70 \mathrm{p}$.

Nuortimo, K. and Härkönen, J. (2018): Opinion mining approach to study media-image of energy production. Implications to public acceptance and market deployment. Renewable and Sustainable Energy Reviews, 96, 210-217.

Prelovšek, P. and Uran, B. (1984): Generalised hot wire method for thermal conductivity measurements. Journal of Physics E: Scientific Instruments, 17, 8, 674-677.

Rybach, L. and Eugster, W. J. (2010): Sustainability aspects of geothermal heat pump operation, with experience from Switzerland. Geothermics, 39, 4, 365-369.

Sass, I. and Burbaum, U. (2010): Damage to the historic town of Staufen (Germany) caused by geothermal drillings through anhydrite-bearing formations. Acta Carsologica, $39,2,233-245$.

Sokolić, Ž., Ofak, J., Igor Sokolić, Dobrilović, I., Miklin, Ž., Podolszki, L., Novosel, T., Borović, S., Lazar, J. M. and Burić, H. (2016): Inženjerskogeološka i hidrogeološka istraživanja - dodatne spoznaje o klizištu Črešnjevec (Engineering geological and geotechnical investigations Additional findings on the Črešnjevec landslide), Geotehnički studio Ltd. and Hrvatski geološki institut, Zagreb, $24 \mathrm{p}$.

Soldo, V., Boban, L. and Borović, S. (2016a): Vertical distribution of shallow ground thermal properties in different geological settings in Croatia. Renewable Energy, 99, 1202-1212.

Soldo, V., Borović, S., Lepoša, L. and Boban, L. (2016b): Comparison of different methods for ground thermal properties determination in a clastic sedimentary environment. Geothermics, 61, 1-11.

Tari, V. and Pamić, J. (1998): Geodynamic evolution of the northern Dinarides and the southern part of the Pannonian Basin. Tectonophysics, 297, 269-281.

Urumović, K. and Urumović K. Sr. (2016): The referential grain size and effective porosity in the Kozeny-Carman model. Hydrology and Earth System Sciences, 20, 5, 1669-1680.

Vandenbohede, A., Hermans, T., Nguyen, F. and Lebbe, L. (2011): Shallow heat injection and storage experiment: Heat transport simulation and sensitivity analysis. Journal of Hydrology, 409, 1-2, 262-272.

VDI (2010): Thermal use of the underground, Ground source heat pump systems, Volume 4640 Blatt 1 - 06/2010: Düsseldorf, Verein Deutscher Ingenieure. 
Velić, J., Malvić, T., Cvetković, M. and Vrbanac, B. (2012): Reservoir geology, hydrocarbon reserves and production in the Croatian part of the Pannonian Basin System. Geologia Croatica, 65, 1, 91-101.

Vieira, A., Maranha, J., Christodoulides, P., Alberdi-Pagola, M., Loveridge, F., Nguyen, F., Florides, G., Radioti, G., Cecinato, F., Prodan, I., Ramalho, E., Georgiev, A., RosinPaumier, S., Lenart, S., Erbs Poulsen, S., Popov, R., Lenart, S., Erbs Poulsen, S., Radioti, G., Javed, S., Van Lysebetten, G. and Salciarini, D. (2017): Characterisation of
Ground Thermal and Thermo-Mechanical Behaviour for Shallow Geothermal Energy Applications. Energies, 10, no. 2044, 53 p.

World Bank Open Data, URL: http://databank.worldbank.org/ data/reports.aspx? source $=2 \&$ series $=$ SP.URB.TOTL.IN.ZS (Accessed $2^{\text {nd }}$ November 2018)

Yang, H., Cui, P. and Fang, Z. (2010): Vertical-borehole ground-coupled heat pumps: A review of models and systems. Applied Energy, 87, 1, 16-27.

\section{SAŽETAK}

\section{Ispitivanje toplinskih vodljivosti materijala u plitkome podzemlju za korištenje dizalica topline u panonskome dijelu Hrvatske}

Termogeološka i hidrogeološka svojstva plitkoga podzemlja u hrvatskome dijelu Panonskog bazena (PBS) istraživana su u kontekstu njegova korištenja za postavljanje sustava dizalica topline s tlom kao izvorom topline (GSHP). Provedene su detaljne determinacije bušotinskih jezgara, uzorkovanja te mjerenja toplinskih parametara za sedam bušotina s četiriju lokacija različitih geoloških obilježja. Sabrani su rezultati ukupno 418 mjerenja provedenih na 82 uzorka sedimenata i stijena te su analizirani u kontekstu postojećih zbirki vrijednosti toplinskih vodljivosti sedimenata i stijena iz Njemačke i Švicarske, koje se često koriste za dimenzioniranje bušotinskih izmjenjivača topline (BHE) i u drugim državama. Utvrđena je razlika u toplinskim vodljivostima između istovrsnih sedimenata i stijena koji potječu iz različitih geoloških sredina. Takvi rezultati upućuju na potrebu razvoja lokalnih setova podataka koji bi omogućili točnije dimenzioniranje izmjenjivača topline. U četirima su bušotinama provedena i testiranja toplinskoga odziva tla (TRT-ovi) te su njihovi rezultati uspoređeni s rezultatima dobivenim direktnim mjerenjem na uzorcima. Usporedba pokazuje da u situacijama kada postoji značajan tok podzemne vode (u krupnije zrnatim sedimentima) mjerenja na uzorcima sistemski podcjenjuju vrijednosti toplinske vodljivosti u odnosu na realno mjerilo, dok su razlike manje kod sitnije zrnatih sedimenata. Zbog toga je pri postojanju značajnoga toka podzemne vode obavezno provoditi TRT-ove, dok se u suprotnome za manje sustave može primjenjivati i analogija s objavljenim podatcima o toplinskim vodljivostima. Važno je imati zbirke takvih podataka zbog slučajeva kada TRT nije ekonomski isplativ. Vrijednosti koje se navode u ovome radu mogu poslužiti kao smjernice za odgovarajuće dimenzioniranje GSHP sustava s ciljem postizanja boljih indikatora, osobito za manje sustave u Hrvatskoj te na drugim geološki usporedivim lokacijama u PBS-u.

\section{Ključne riječi:}

toplinska vodljivost, hidrogeološka svojstva, dizalice topline s tlom kao izvorom topline, Panonski bazen, Hrvatska

\section{Authors' contribution}

This manuscript was planned in the scope of thermogeological research of the projects "GeoMapping" and "Detailed engineering geological map of the Podsljeme urbanized zone”. Staša Borović ( $\mathrm{PhD}$, Research Associate) coordinated the realisation of the manuscript and was responsible for Sections 3 and 4. Section 2 was supervised by Ivica Pavičić (PhD, Research Assistant), Sections 1 and 5 by Kosta Urumović (PhD, Research Associate) and Josip Terzić (PhD, Research Advisor). The authors formed a collaboration group which has worked closely together in all production stages. All authors provided fieldwork, technical, theoretical and practical support and reviewed and approved the final version of the manuscript. 